\title{
LARES DE CUIDADO E LINHAS DE SUCESSÃO: ALGUMAS INDICAÇÕES ETNOGRÁFICAS NA FRANÇA, HOJE
}

Florence Weber

Em meus estudos etnográficos anteriores sobre a estrutura das classes trabalhadoras na França rural (Weber 1989, 1998, 2006), foi mostrada a importância da economia doméstica como cenário social separado da economia de mercado e da economia pública, embora articulado a estas. ${ }^{1}$ As relações pessoais, em tal cenário, são configuradas pela solidariedade (em uma unidade de sobrevivência) ou pela reciprocidade (entre dois indivíduos ou entre duas unidades de sobrevivência). Para estudar essas relações pessoais, e não obstante a coloração afetiva que têm, devemos levar em conta sua violência simbólica, e por vezes física, bem descrita pelo termo dominação pessoal - seja "tradicional" ou "carismática", nas palavras de Max Weber — vinculada à dimensão agonística da "dádiva maussiana" e reforçada pelas dívidas pessoais, como mostrou Pierre Bourdieu (1977). Voltei-me, então, para o estudo do trabalho pago ou não-pago de cuidar de crianças, idosos e pessoas com deficiências, dada a importância crescente desse tipo de atividade na política e na economia francesas, e o óbvio interesse que o assunto tem para o estudo da articulação entre economia doméstica, mercado e Estado.

Logo percebi que, para entender as formas e os significados das atividades de assistência, seria preciso analisar o parentesco como conjunto de obrigações morais e legais - inclusive a obrigação de tomar conta e cuidar², mas também como conjunto de direitos econômicos e políticos para a transmissão simbólica e material. Como sabem os antropólogos, o parentesco não é apenas uma rede de relações recíprocas (homens trocando mulheres, se seguirmos a teoria de Lévi-Strauss), mas também uma articulação um tanto difícil entre dois grupos integrados: a unidade doméstica como unidade de sobrevivência (o grupo de residência estudado por antropólogos marxistas) e o grupo de descendência como linha de sucessão (a linhagem, primeiramente estudada por antropólogos britânicos e, a seguir, por historiadores). ${ }^{3}$ 
Também tive de levar em conta a dimensão de gênero que tem o parentesco, ainda que tal dimensão não tenha efeitos simples no contexto francês, em que homens e mulheres podem igualmente transmitir bens e status sociais - exceto no que diz respeito ao sobrenome, que não é dependente de gênero se os pais não forem casados, mas que, até uma lei recente, passava do pai para os filhos nascidos dentro do casamento. Em tal contexto, as obrigações morais e legais de cuidar são recíprocas, seja entre marido e mulher (sob o termo de "solidariedade conjugal") ou sob o termo de "dever filial" e "obrigação familiar de sustento", entre pais e filhos (sem distinção entre pai e mãe ou entre filho e filha). No entanto, concentrei minha atenção em estudos de casos nos quais, em algumas ocasiões e por determinados períodos, os homens estavam ausentes $\operatorname{do} \operatorname{lar}^{4} \mathrm{e}$, mais excepcionalmente, das linhas de sucessão. ${ }^{5}$ Precisamente por não parecerem "naturais" às pessoas que as experimentam, essas situações permitem ao observador compreender a natureza do parentesco e suas dimensões legais, ideológicas e afetivas.

A ausência de homens - pais, cônjuges vivos, irmãos, filhos - tem muitas implicações para as mulheres. Nesses casos, elas devem tanto suprir o dinheiro necessário (proveniente do trabalho ou de auxílios sociais) aos parentes dependentes, quanto oferecer-lhes algum conforto doméstico, por meio de atividades não-pagas que podem ser tradicionalmente femininas (cozinha, tarefas domésticas, saúde) ou masculinas (consertos do carro ou da casa, preenchimento de documentos administrativos, lidar com bancos). Além disso, o sistema de seguro social na França foi concebido em um mundo em que se supõe que os homens são, em termos legais e econômicos, os chefes da casa. Sua ausência cria desafiliação, mudando a relação entre os indivíduos e o Estado social. Os políticos e os intelectuais franceses devem hoje redefinir um Estado de bem-estar social que seja adequado a novas configurações da família. É uma tarefa difícil, e temos primeiramente que descrever e entender o que se passa nas famílias, consideradas como lares de cuidado e como linhas de sucessão.

Conduzi por seis anos um trabalho de campo que me levou da área de Paris para vários lugares onde vivem parentes de meus primeiros contatos. ${ }^{6}$ Em 1998, para ser introduzida no campo, segui Sophie, uma francesa de 40 anos, executiva casada e com três filhos. Ingressei em seu ambiente profissional, percorri sua rede na escola primária de seus filhos, e ingressei nos vários ambientes sociais de Aicha, marroquina que há muito tempo é a empregada doméstica de Sophie, tendo antes trabalhado para a mãe de Sophie, já falecida. Por meio de Sophie e de Aicha, encontrei várias famílias sem homens, de diversas origens sociais, e entrevistei muitas pessoas em cada uma delas, mesmo quando moravam em lugares distantes. 
Através das três histórias que apresento aqui, procuro examinar, no contexto francês, as diferenças entre paternidade e maternidade em suas faces jurídica e ideológica; as diferenças entre maternagem e paternagem, em suas dimensões morais e afetivas; e entre cuidar de filhos menores e cuidar de pais idosos, do triplo ponto de vista da responsabilidade legal (quem deve pagar), das transações econômicas (quem dá e quem recebe assistência paga e não-paga) e dos sentimentos morais (sentido de vínculo natural, senso de dever, amor eletivo, sentimentos construídos no dia-a-dia). Tentarei então abordar as implicações políticas dessas diferenças.

\section{Uma ação judicial de contestação de paternidade}

Por meio da história de Berenice, colega de Sophie, de 30 anos, que teve três pais - um pai oficial, isto é, o marido da mãe na época em que Berenice nasceu; um pai biológico, o amante da mãe quando Berenice foi concebida; um pai de criação, o marido da mãe durante a infância de Berenice - e, afinal, nenhum, pois o primeiro contestou a paternidade, o segundo nunca apareceu e o terceiro não cumpriu seu papel na transmissão social, analisarei as dimensões jurídicas e ideológicas da paternidade em uma linha de transmissão (de nome, patrimônio e status) e as dimensões financeiras e afetivas da paternagem em uma série de lares de cuidado.

Berenice nasceu em 1969, como filha de pais casados - Annick e Simon. Conheci-a em 2000, após a ação judicial que seu pai jurídico moveu contra ela em 1997, alegando não ser seu pai. Entrevistei-a várias vezes, e entrevistei Annick em 2001. Berenice me deu acesso a todos os documentos usados no processo, declarações, papéis do divórcio, cartas e toda a correspondência que manteve com Simon e a família dele.

Quando Berenice nasceu, seus pais eram muito jovens -20 anos de idade - e ainda dependiam legalmente de seus próprios pais. Na época, a idade mínima para se ter direitos civis plenos era de 21 anos (hoje é de 18 anos). A mulher, Annick Berger, era uma das três filhas de um político local de uma cidade pequena, e que havia sido professor e se casara com uma professora. A própria Annick é professora de francês. O marido, Simon Sirius, era estudante de medicina e dependia financeiramente da mulher. Ele veio a se tornar um médico rico, de carreira internacional. Seus pais eram professores também.

Annick e Simon tinham relações sexuais antes do casamento, e Annick teve de fazer um aborto na Suíça, quando engravidou pela primeira vez. Nessa época, o aborto era ilegal na França. Teve então um caso com um jovem 
de 17 anos, seu aluno. Quando Simon e Annick se casaram, ela estava grávida pela segunda vez, e contou a Simon que a criança talvez não fosse dele. No entanto, ela decidiu dar continuidade à gravidez. Quando Berenice tinha um ano de idade, em 1971, Simon e Annick se divorciaram — na época, não havia na França divórcio por consentimento mútuo, mas apenas litigioso.

Tenho duas versões desse divórcio. A primeira é o depoimento, perante a corte, do pai de Simon, Lucien; foi escrito em 1997 para apoiar o filho no processo de contestação da paternidade. Permito-me citar diretamente o documento:

Meu filho Simon casou com a srta. Annick Berger em 1969. No início de 1971 ele me disse que havia decidido separar-se da esposa após ter ela lhe contado que ele não era o verdadeiro pai de Berenice, minha neta, nascida de seu casamento em 1969.

Preocupado com essa situação, e ansioso por aconselhar o casal da melhor maneira, de preferência com a concordância dos pais de Annick, tomei a iniciativa de visitá-los. Cheguei à residência dos Berger sem avisá-los de antemão.

A sra. Berger disse-me que sabia dos fatos e que sua filha Annick lhe havia dito que meu filho não era o pai biológico da pequena Berenice. O sr. Berger, que nada sabia da situação, juntou-se então a nós.

Chegando a um acordo, ele e eu decidimos ir à casa de nossos filhos e tentar esclarecer a situação.

Chegamos às 11. Meu filho estava sozinho e sua mulher só chegou à 1 hora e confirmou para seu pai que: 1. ela não havia passado a noite em casa; 2 . a pequena Berenice não era filha de seu marido.

Diante dessa situação difícil e dolorosamente clara, todos concordamos que nunca seria possível um casamento estável e que uma separação rápida e amigável dos jovens esposos seria a solução mais simples para todos os envolvidos. Chegamos à decisão consensual de que: 1. a esposa adúltera deixaria o domicílio conjugal o mais rapidamente possível; 2. os trâmites do divórcio seriam iniciados imediatamente; 3 . ela aceitaria todos os custos e não exigiria pensão para si nem para a criança - até quanto sei, todas essas condições foram estritamente cumpridas; 4 . ela ficaria livre para começar uma nova vida e criar a filha do modo que julgasse adequado.

Meu filho não reivindicou nenhum direito de paternidade, pois reconheceu não ser o pai. Essa condição também foi cumprida, até quanto sei.

Não tive mais contato com os Berger, sua filha Annick ou sua neta Berenice, embora o lamente, e minha mulher o tenha lamentado até morrer. Não pudemos mais voltar a considerar a pequena Berenice como nossa neta. 
Essa versão da história mostra quão violenta se tornou a situação, e como o velho Lucien Sirius fez-se ao mesmo tempo agente e vítima de tal violência. Agente: é ele quem decide comunicar ao pai de Annick, informar publicamente (ainda que seja um público formado por parentes afins) a "verdade" sobre o adultério, e descobrir as implicações dessa "verdade". Mas também vítima: sua emoção, tantos anos depois, ainda está presente. Ele comete vários lapsos ao escrever seu depoimento e, a cada vez, tem de repetir "meu filho não é o pai". Ele também afirma no início do texto que Berenice é "minha neta, nascida de seu [de Annick e Simon] casamento" e termina constatando "não pudemos mais voltar a considerar a pequena Berenice como nossa neta". Mas ele não é a única vítima dessa violência: ele insiste no sofrimento de sua esposa. Não insiste no sofrimento de seu filho, Simon, mas encontraremos adiante alguns traços desse sofrimento.

Para saber até que ponto a situação foi dolorosa para Annick, passarei à sua perspectiva sobre o rompimento em 1971, apresentando alguns trechos da entrevista que fiz com ela em 2001:

Eu sei que fui embora em algum momento dizendo a ele que ela não era sua filha, o que era absurdo [ela se refere ao fato de que não tinha como saber se era ou não verdade a não-paternidade de Simon, e que todos deveriam saber que ela não poderia sabê-lo], me responsabilizando por tudo [no processo de divórcio] e, eu diria, que para salvar nossas peles. Porque ele, no fim das contas, é alguém que... ele me batia na frente dela, na frente de uma criança, se aproveitou quanto pôde da situação. Hum, lembro da Berenice chorando no trocador [de fraldas] enquanto o pai me batia cruelmente...

Foi, hum, foi uma fuga, sabe... Eu fui embora, fui embora com uma sensação de ter salvo minha vida... Eu não podia agüentar aquele ambiente em que o acordo entre nós, ainda por cima, era 'a criança sendo minha ou não (foi isso que ele disse, porque eu não escondi dele a verdade), em qualquer caso, o que importa? - mas quando nós discordarmos, quem manda sou eu...'

Eu estava grávida, foi por isso que me casei com Sirius, sabe... na base do 'tá certo, tá certo, ok, você se casa comigo, tá bom? Tanto faz se a criança é minha ou não, hum, de um jeito ou de outro não é o fim do mundo casar e ter filho, mas você tem que me obedecer, e se tiver uma briga, quem manda sou eu'.

Eu corria perigo, sabe? Não foi 'de cara', e não foi fácil, e de jeito nenhum simples no nível financeiro, e naquele tempo um divórcio era difícil... Então resolvi... arcar com toda a responsabilidade... Entramos com um divórcio - não se podia falar em divórcio amigável naquele tempo. Nós dois entramos com o pedido de divórcio, mas os juízes imaginaram bem rápido que eu queria me separar mais do que ele. 
Fiquei extremamente surpresa quando Annick me contou sua versão do divórcio. Quando li o depoimento, vi a reunião de família pelos olhos de Lucien, como um tribunal informal que julga o adultério de uma mulher, condenandoa ao divórcio. É claro que Annick me contou quão desagradável fora aquele encontro, com os dois homens mais velhos, seu pai e seu sogro, chamando-a de prostituta e jogando sobre ela a culpa. Mas descobri que o divórcio foi um alívio para ela e que, em certo sentido, ela havia ganho a batalha.

Tendo em mente a versão de Annick, voltemos atrás, aos quatro itens do que Lucien chamara de "decisão consensual": 1. a esposa adúltera deixaria o domicílio conjugal assim que possível — Annick contou-me que ela já havia saído de casa; 2. os trâmites do divórcio seriam iniciados imediatamente - Annick me disse que ela queria o divórcio "mais do que Simon"; 3. ela arcaria com todos os custos financeiros e não demandaria pensão - podemos agora dizer que estava pagando por sua liberdade; 4. ela estaria livre para começar nova vida e criar a filha como achasse melhor. Simon não exigiu direitos de paternidade por reconhecer que não era o pai.

Este último ponto é o mais importante. Há dois fatos distintos aqui. Um é que Annick tinha ao mesmo tempo um amante e um (futuro) marido. O outro fato dizia respeito à impossibilidade de responder, na época, se Simon era ou não o pai. Annick afirmava que não. No início, Simon disse a Annick que não se importava, mas que dominaria a esposa por causa de seu "delito" sexual. A violência mesma, para Annick, estava nesse estranho arranjo: ela errara e ele decidia tudo. Depois de um tempo, ela não pôde mais suportar a situação e deixou, com o bebê, o lar, salvando suas peles, como ela diz.

Antes da violência do encontro, em que o pai do pai teve papel destacado como agente e também como vítima, houve a violência dentro do casamento, violência física e moral de Simon em relação a Annick. Mas vemos agora que a violência do encontro foi também a contrapartida da resposta de Annick à violência do marido, quando ela desfez a paternidade apenas pela força das palavras. Ela mostra que está consciente quanto ao tipo de violência que exerceu então, ao me dizer que contou a ele que a criança "não era sua filha, o que era absurdo".

O epílogo dessa parte da história se deu em 2000, quando Simon ganhou o processo movido contra Berenice, de contestação da paternidade. Até o processo, o sobrenome que constava na certidão de nascimento de Berenice era Sirius, e ela era a filha de Simon Sirius e de sua ex-esposa, Annick Berger. O divórcio não havia alterado esses fatos, mas Simon desapareceu completamente do lar de cuidado: nunca pagou um centavo e jamais viu Berenice. Ele a procurou quando ela tinha 29 anos, sabendo que, pela lei francesa, 30 anos é o limite para a contestação da paternidade. 
Na França, há três passos em uma ação judicial desse tipo. Primeiro, o pai legal deve provar que nunca tratou a criança como sua filha (ou filho) - em outras palavras, que ele jamais dela cuidou como pai. Como segundo passo, caso ele tenha convencido o tribunal acerca desses fatos sociais, será requisitado dele um exame de sangue. O terceiro passo, se o exame de sangue mostrar que ele não é o pai biológico, é a declaração, pelo tribunal, de que ele não é juridicamente o pai. Esses três passos correspondem a três dimensões da paternidade: a social (paternagem), a biológica (sangue), a legal (sucessão). De acordo com a lei francesa, se se tratar de um pai adotivo, ou se ele se tornou pai por tecnologia de fertilização in vitro (FIV) como doador de esperma, a dimensão do sangue desaparece, e são apenas esses pais específicos (adotivos ou por FIV) que não têm como contestar a paternidade.

O fato de Simon ter ganho de causa deveria trazer duas conseqüências para Berenice: modificação de seu sobrenome e deserdação. Mas antes de ir à justiça, Simon tentou um acordo com Berenice. Ele assumiria todos os gastos da ação, e Berenice poderia manter seu nome. Ela aceitou a ação nessas condições. Para convencer o tribunal, ela teve de mostrar que a modificação do nome seria prejudicial e, para isso, usou o fato de ser profissionalmente conhecida como Berenice Sirius. A sentença final seguiu o acordo entre os dois.

Há dois episódios, mais uma vez, que mostram a violência do lance final de uma situação bem dolorosa. Primeiro, Annick e Simon, quando se submeteram ao exame oficial de sangue para fins legais, tiveram de se encontrar brevemente - o que aconteceu pela primeira vez desde o divórcio. Simon tornara-se um brilhante médico de carreira internacional, rico e bonito, e Annick tinha a aparência de uma velha e cansada professora de escola. Berenice notou o contraste e ficou consternada ao ver sua mãe passar por tal situação desagradável. Depois, após o exame confirmar a intuição irracional de Annick, mas antes do julgamento propriamente dito, Simon sofreu um acidente de montanhismo e morreu. Após sua morte, a viúva deu prosseguimento à ação judicial. Simon se casara com uma jovem e bonita mulher, e eles não tiveram filhos. Com a ação, ele pretendia proteger sua segunda esposa e torná-la sua herdeira. Mas em seu encontro com Berenice, ele teve um comportamento ambivalente: deu-lhe alguns presentes, falou de como ela era quando bebê, e sonhou, por pouco tempo, que ela poderia afinal ser sua filha biológica. Mas ela não era. Creio, embora não possa prová-lo, que Simon teve um forte envolvimento emocional nessa história.

Para concluir esta primeira parte da história de Berenice, direi que ela mostra a força da ideologia do sangue. Ele tem um poder destrutivo. Não 
basta o sangue para fazer um pai: nunca vimos o pai biológico de Berenice, esse jovem de 17 anos que desapareceu rapidamente, que nunca mostrou se importar com a filha biológica. Berenice chegou a procurá-lo; localizou-o, encontraram-se, porém nada se criou entre eles. Por outro lado, a ausência do sangue é bastante para desfazer a paternidade, e até para desfazer os laços de avô e avó, mesmo depois de um ano de amor e carinho. Para seus avós, e talvez para Simon, Berenice morreu como filha e neta quando tinha um ano de idade.

\section{Um pai dedicado}

Passemos agora à segunda parte do caso. Berenice foi criada pelo segundo marido de sua mãe, Nathan Norman, assistente social e filho de uma família de comerciantes imigrados. Ela ainda o chama de "papai". Annick casou-se com Nathan quando Berenice tinha quatro anos. A menina sabia não ser ele seu pai oficial (o sobrenome dela é Sirius), e até os oito anos de idade acreditou que ele fosse seu pai biológico (o misterioso amante da mãe). Quando nasceu Alba, a irmã de Berenice, o casal se desentendeu e Annick, diante da filha mais velha, disse que Nathan não era seu pai - momento doloroso que é uma forte lembrança para Berenice. Nathan e Annick então se separaram, em 1985, e esse segundo divórcio foi bem diferente do primeiro. Desde 1975 existia na França o divórcio por consentimento mútuo. Annick e Nathan foram à justiça com um acordo amigável, concedendo direitos de paternidade a Nathan e subseqüentemente dividindo os custos dos cuidados e da educação - porém apenas da segunda filha, Alba. O divórcio mostrou bem claramente que Berenice não tinha nenhum vínculo legal com Nathan.

Eis alguns trechos de minhas entrevistas com Berenice, de modo a apresentar sua própria perspectiva a respeito do relacionamento com Nathan:

Dá até para dizer que nós ficamos muito próximos depois do divórcio, e mesmo antes do divórcio, bem, por muitas razões, porque por contraste foi como uma vingança. Afinal de contas, houve um período em que eu estava muito mais do lado da mamãe em todas as discussões, mas durante algum tempo foi justamente o contrário.

Foi um presente, sabe, porque se Nathan não era meu pai biológico, tudo o que tem a ver com amor é uma dádiva, vira algo a mais; já se ele fosse [o pai biológico], eu talvez achasse que ele era meio retraído; ele não sendo, estava acima e além. E antes e depois de tudo, eu adorava papai. 
- E Nathan dava a você algum tipo de mesada, depois do divórcio?

Ah, não. Eu recebia de outros. Eu sei que tive uns períodos ruins com Nathan, eu disse que nunca recebi um centavo dele, não posso negar que pensei muito nisso. É... com papai é uma relação bem intelectual, mas em termos materiais não é nada, e nunca foi de nenhum outro jeito.

Foram quase só os meus avós, pais da minha mãe, que pagaram meus estudos, e não meus pais. Quando eu estudava, o dinheiro, metade do dinheiro, não, no máximo um terço vinha da mamãe, e o resto, dos meus avós. Mas com a minha irmã Alba era diferente. Tinha um fluxo constante de dinheiro passando de Nathan para ela; não tanto comparado à mamãe, porque ele ganha menos que ela. Quanto a mim, quanto menos eu devesse à minha mãe, melhor, então eu sempre recorria aos meus avós.

Mesmo eu percebendo que tudo isso me faz ser um pouco... amarga, a falta de apoio do papai, porque é isso que, que, que faz... Não acho que o senso de responsabilidade paterna é o suficiente para que eu realmente queira que ele seja legalmente meu pai.

Nathan nunca se ausentou da vida de Berenice. Ele cuidou dela durante a infância e a adolescência. Ainda há amor entre eles, e cuidado mútuo. Mas é preciso lembrar o contexto dessa entrevista. Conversei com Berenice para poder compreender, após o processo judicial, o que significava um pai, o que significava ter uma relação pai-filha. Ao falar comigo, ela comparou os três pais. Primeiro, disse que Simon lhe deu o sobrenome, e falou dele como "o homem que tem o mesmo sobrenome que eu". Então, me disse da tentativa de iniciar uma relação com seu pai biológico, logo interrompida ao perceber que nesta nova família não havia lugar para ela. No fim, ela voltou ao relacionamento com Nathan. Em algum momento do passado, ela quis que Nathan a adotasse, e agora lamenta que ele não o tenha feito. Ela enfatiza para mim o relacionamento puramente eletivo que sempre teve com ele. O amor dele foi uma dádiva, não um dever. No entanto, ela sabe que deve aos avós, não a ele, e nem mesmo à mãe, seu destino social. De fato, ela se tornou uma cientista brilhante e herdou a boa posição social de seu avô, ao passo que a irmã, Alba, com 25 anos e sem um emprego regular, preserva a posição social de Nathan.

\section{Quatro linhas de sucessão}

Concluamos toda a história de Berenice examinando a situação não do ponto de vista dos lares de cuidado, mas das linhas de sucessão. Podemos resumir afirmando que há quatro linhas de sucessão. 
A primeira vem dos pais de Annick e claramente chega apenas até Berenice, não até Alba. Ainda que os pais de Annick tenham amor por Alba, não lhe transmitiram sua posição social, como fizeram com Berenice. Em relação a esta, eles conscientemente procuraram compensar a ausência de um pai, tornando-a herdeira de uma descendência matrilinear.

A segunda linha vem dos pais de Nathan e claramente chega a Alba apenas. Ainda que os pais de Nathan tenham tratado bem Berenice durante o tempo em que ela viveu com Nathan, após a separação, eles ficaram muito mais próximos de Alba do que dela. Sucessão e deveres mútuos vinculam os pais de Nathan a Alba, não a Berenice.

A terceira linha vem do misterioso pai biológico de Berenice e claramente chega apenas ao filho que ele teve com a esposa. A aparição de Berenice causou tensão na família de seu pai biológico, e o encontro com ele deixou a esposa e o filho apreensivos com a idéia de que Berenice poderia tornar-se legalmente sua filha. Ela logo deixou de considerar o assunto.

A quarta linha é muito interessante. É preciso, quanto a ela, lembrar a importância do sangue para Simon e seu pai. E, no entanto, atentando-se bem para a ação judicial, e lendo-se a correspondência entre Berenice e a família de Simon, descobre-se que a segunda mulher deste, uma imigrante que estava sozinha na França, foi adotada afetivamente pelo pai de Simon como a filha/neta que ele nunca teve. O patrimônio de Simon passou para ela e o processo foi uma forma de protegê-la do retorno de Berenice. Na condição de nora, ocupou o lugar de filha/neta na linha de sucessão. O velho Lucien Sirius sobreviveu à esposa e aos dois filhos (alguns anos antes da morte de Simon em um acidente, seu irmão se suicidara). As viúvas dos dois filhos ficaram próximas, cuidando de Lucien em seus últimos anos de vida.

Podemos assim completar nossas conclusões a respeito da paternidade pelo sangue. Na França, atualmente, o sangue não é condição suficiente para determinar a paternidade legal — já que, através da "suposição da paternidade", o homem com quem uma mulher está casada é o pai presumido dos filhos de sua mulher, e o sangue não conta e, fora do casamento, o pai é aquele que reconhece a criança, o sangue não contando diretamente - nem para definir quem assume os cuidados paternos (pense-se no pai de Berenice "pelo sangue", que desaparece). Vimos que o sangue pode ser necessário para preservar um pai jurídico que não é mais o responsável pelos cuidados caseiros (pense-se em Simon), ou para transformar o pai responsável em um pai "real" (pense-se em Nathan). Mas vimos também quão fortemente os lares de cuidado e as linhas de sucessão podem estar articulados. Os pais da mãe de Berenice incluíram-na no seu grupo de descendência, atuando como pais nos aspectos dos cuidados e da transmissão de status. A viúva de 
Simon vem sendo simultaneamente a herdeira do grupo de descendência de Lucien e aquela que cuida pessoalmente dele. Se na produção da paternidade o sangue tem poder destrutivo e não construtivo, de que modo se dá a interação dos fatos biológicos e sociais no caso da maternidade? Mais ainda: será que essa articulação entre o lar de cuidado e a linha de sucessão é marcada pelo gênero?

\section{Pobre e solteira: mãe desprovida}

Passemos agora à relação mãe-filho(a). Parece ser bem mais simples. Uma mãe é uma mãe, este é o tipo de evidência que nunca se deveria contestar. ${ }^{7}$ No entanto, o caso de Helena, mãe solteira desprovida pelo governo e pelas instituições de caridade, mostrará que a questão não é tão simples quanto nos pode parecer.

Helena, mãe solteira de 50 anos, conheceu meu contato inicial, Sophie, devido ao fato de os filhos de ambas terem estado na mesma escola, em certa época. Ela criou seus dois filhos sustentada apenas pela pensão de invalidez. Sua história permitirá que examinemos o processo de privação de direitos movido pelo Estado social e pelos agentes de filantropia contra as mães solteiras. As mães, em comparação com os pais, não têm na França direitos de maternidade, apenas deveres de maternagem.

Os filhos de Helena nasceram em 1989 e 1990, no início de um período de enorme aumento, nos países ocidentais, do número de crianças nascidas fora do casamento. Ela nunca se casou com seu parceiro sexual, nem viveu com ele. Ele reconheceu os filhos e lhes deu o nome de família. Mas Helena teve de contar apenas com seus próprios recursos - econômicos, afetivos e de tempo disponível. O lar de cuidado, reduzido à mãe e aos filhos, vive da pensão que ela recebe. Ela nunca teve um emprego.

Olhando-se o diagrama das relações afins (ao final deste artigo), vê-se o quanto estão isolados mãe e filhos. Helena tem uma irmã que ficou com todos os parcos recursos dos pais - imigrantes espanhóis que tudo perderam ao migrar. O parceiro de Helena teve um filho de um casamento anterior, e a esse filho foi transmitido o status social elevado dos pais (a ex-mulher é professora universitária, e ele é um artista de nível técnico). Já os filhos de Helena não estão em nenhuma linha de sucessão. Quando a conheci, em 2002, ela tinha se mudado do bairro de classe alta em que conheceu Sophie para um bairro ao qual não se adaptou. Ela acusa os assistentes sociais de incompetentes. Sua pensão foi suspensa sem nenhuma razão e ela se queixou de lhe ter sido tirada a autonomia. 
Permito-me transcrever alguns trechos de uma carta que ela, desesperada, escreveu na ocasião a um médico que conhecera quando jovem.

Quero de volta meus direitos, minha liberdade, minha autonomia como pessoa, talvez incapacitada para um emprego, mas não para ser mãe. E me sinto capaz de ser mãe, e quero ser, e é uma tarefa difícil, mas é o trabalho que escolhi, cuidar de meus filhos, com a ajuda espontânea de pessoas que realmente querem nos ajudar.

Helena insiste em "ajuda" e em "ajuda espontânea", porque, de maneiras diversas, já se deparou com suspeitas de que não estivesse apta a ser mãe. Um juiz deu a um assistente social o poder de decisão com respeito aos filhos. Helena aceitou a ajuda caridosa de padrinhos. Um deles não a respeitava como mãe. Ela prossegue:

Precisamos receber minha pensão de invalidez e os direitos sociais sem intermediários, como sempre recebemos. Preciso receber dos assistentes sociais informações, e eles devem ser objetivos, neutros, respeitar nossa integridade pessoal e liberdade [...]. Não quero ser uma escrava moderna mantida sob tutela por ser uma pessoa sozinha e pobre.

Essa reivindicação mostra a diferença entre o mundo em que Helena foi socializada - um mundo de direitos sociais e orgulho da classe trabalhadora (seus pais foram militantes da República Espanhola durante a guerra civil contra o fascismo) - e o mundo em que vive atualmente, o de um Estado social em dissolução que se torna um governo de caridade para os pobres. Ela passou pela experiência dessa diferença na qualidade de não-trabalhadora, pobre e mãe solteira.

Ela termina a carta com as seguintes palavras: "Para mim, todo o trabalho ruim, as tarefas braçais e o fardo mental. Para eles [o juiz, os assistentes sociais, os assim chamados padrinhos leigos de seus filhos], o julgamento, o poder de tomar as decisões, um poder ditatorial".

A distinção que Helena faz aqui tem a ver com a distinção entre responsabilizar-se e cuidar (Tronto 1993). Helena tem o direito de cuidar de seus filhos (ao qual ela se refere como "o trabalho ruim, as tarefas braçais e o fardo mental"), mas não o direito de ser responsável por eles (ao qual ela denomina de "o poder de tomar as decisões").

Historiadores mostraram que em alguns casos o Estado de bem-estar social comportava-se, em relação às mães solteiras, como pai (Thébaud 1993). O caso de Helena sugere que há apenas duas dimensões da maternidade, 
e não três, como vimos ser o caso na paternidade. Helena, para seus filhos, é mãe biológica e aquela que cuida. Mas ela se sente privada dos "direitos maternos", provavelmente por não haver atualmente, na França, nada similar aos "direitos maternos".

\section{Dever filial e o novo benefício francês para os que cuidam}

Se vimos a diferença, em um contexto francês, entre paternidade (com três dimensões imbricadas) e maternidade (com apenas duas dimensões), tentemos agora entender, ainda no contexto francês, a diferença entre cuidar de filhos e cuidar de idosos.

Saliha, francesa-argelina de 50 anos, toma conta da mãe dependente e cuida dela em sua própria casa, recebendo um benefício em troca desse trabalho de assistência. Por meio da comparação entre ela e Helena, procurarei compreender por que a política francesa criou recentemente um status de assalariado para filhas que cuidam das mães idosas, mas não para mães que cuidam dos filhos.

Saliha mora na França desde a infância. Seu pai era trabalhador imigrante e membro de uma rica família que colaborou com o governo colonial francês antes da independência da Argélia. Encontrei-a porque ela era vizinha e amiga próxima da empregada de Sophie, Aicha. Foi militante comunista por mais de 30 anos, antes de se tornar muçulmana religiosa, em meados da década de 1990. É respeitada como autoridade moral pelas famílias muçulmanas do bairro onde vivem trabalhadores — mas não pobres — franceses e imigrantes.

Por muito tempo, Saliha trabalhou como secretária de um advogado. Depois, casou-se com um negociante egípcio que possuía uma oficina mecânica, e trabalhou para ele dando-lhe ajuda familiar informal, sem salário nem registro profissional. Não teve filhos com ele. Seus pais estão vivos, muito idosos e doentes. Sua mãe sofre de mal de Alzheimer e Saliha teve de trazê-la para morar em sua casa. Quando o fez, o marido discordou e lhe disse para "escolher entre ela e eu". Ela respondeu: "só tenho uma mãe, é ela". O marido saiu da residência conjugal e desde então fica em casa de amigos.

Saliha tem dois irmãos que vivem fora do país - um é médico e o outro, engenheiro - e uma irmã que vive em Paris, tem bom emprego e uma criança pequena. Quando Saliha quer viajar, pede que a irmã a substitua.

Desde 2002, há na França um novo benefício para os idosos, que recebem certa quantia para pagar o acompanhante - seja este membro da família ou não. Saliha recebe tal benefício, e permito-me citá-la para mostrar de que modo ela fala sobre isso. 
Prefiro eu mesma cuidar dela, porque... ela não quer mais ninguém, sabe? Mesmo se o governo não me pagasse, eu teria ficado com minha mãe. Mas o auxílio é importante, não só pelo dinheiro, mas porque me dá registro no seguro social. Se eu me inscrevesse na Agência de Empregos, mais dia menos dia eles me chamariam e eu teria que dizer que não fico com o emprego.

Comparem-se agora os casos de Helena e de Saliha, do duplo ponto de vista do parentesco e das políticas sociais. Por que foi possível, na França, conceber e criar um benefício para "filho-que-cuida-de-pai-idoso" e não um benefício para "mãe-que-cuida-de-filho"? Parece-me que ser mãe dedicada é considerado um comportamento natural, ao passo que ser filho dedicado é considerado um comportamento moral. O Estado Social quer incitar os filhos a cuidarem de seus idosos; por outro lado, ninguém precisa incentivar a mãe a cuidar de seus filhos. Além disso, remunerar a mãe seria visto como um meio de tirar as mulheres do mercado de trabalho. É estranho que pagar a filha para cuidar da mãe não implique o mesmo temor. Talvez porque as filhas que cuidam das mães já são bastante velhas e, por isso, aposentadas. Talvez porque alguns governos de direita (de Vichy ao período gaullista) promoveram, até 1974, o "salário materno" sob a forma de um auxílio às famílias com um único salário.

\section{Algumas conclusões}

A comparação dos casos de Helena e de Saliha mostrou como é diferente para mães e filhas se verem presas a uma situação em função de cuidar e de se importar. Helena não tem companheiro, nem apoio de parentes. Saliha é casada, tem dois irmãos e uma irmã, e sua mãe é casada. No entanto, fica sozinha com a mãe; é a única que sente forte obrigação em relação a ela. Esse sentimento de obrigação tem a ver com a disponibilidade de Saliha: não tem filhos e já não tem um status profissional. Poderíamos pensar também em uma razão cultural: Saliha é muçulmana, provavelmente mais carregada de valores religiosos do que sua irmã mais nova. Mas os resultados dos levantamentos mostram que o senso do dever em relação a mães idosas é comum, independente da religião, a muitas francesas da geração de Saliha que não têm filhos dependentes nem profissão. A comparação entre os casos de Berenice e de Helena mostrou o quanto é diferente, para homens e mulheres, estar ou não envolvido na criação de filhos, e como é fácil para os homens desaparecer, mesmo quando não o desejam (veja-se Nathan, que criou Berenice), ou mesmo quando não deveriam fazê-lo (veja- 
se Simon, o pai legal de Berenice). Em contraste, Helena continua a cuidar de seus filhos, mas neste momento já não lhe é permitido tomar decisões em relação a eles.

Essas três histórias mostraram os modos diferentes com que os homens desaparecem das famílias. Eles podem desaparecer dos lares de cuidado na condição de companheiros vivos (pense-se no parceiro sexual de Helena, ou no marido de Saliha); de pais (mas divorciar-se não significa desaparecer do lar — pense-se em Nathan, pai de criação de Berenice); ou na condição de filhos (pense-se nos irmãos de Saliha). Nos limites deste artigo, não pude mostrar que o cuidado de idosos não é assunto só de mulheres. Direi apenas que o comportamento de um filho solteiro é semelhante ao da filha solteira: o envolvimento não está apenas ligado ao gênero, mas também, de modo marcante, à estrutura do círculo de parentes. Em um número menor de casos, os homens podem desaparecer das linhas de sucessão. Obviamente, o caso de Berenice é o melhor exemplo, com o desaparecimento, primeiramente, de seu pai biológico, a seguir de seu pai legal, e finalmente de seu pai de criação, Nathan. Mas o caso de Helena mostra que o pai pode estar ausente de qualquer forma concreta de transmissão, mesmo quando reconhece oficialmente os filhos.

Para concluir, gostaria apenas de sugerir três direções de pensamento.

1. A vida cotidiana cria relacionalidades ${ }^{* 8}$, mas constitui a dimensão negligenciada do parentesco, ao menos na França. Por exemplo, os debates franceses sobre famílias reconstituídas não distinguem entre pai/mãe afim (o padrasto ou a madrasta, o cônjuge de um dos pais) e pai atuante - aliás, a língua francesa não tem um termo para "pai (ou mãe) de criação", a não ser o termo jurídico de "pai (ou mãe) adotivo(a)". Ao contrário, a ideologia do parente de sangue parece desmesuradamente aumentada na sociedade francesa, e mesmo no direito civil. Os juízes procuram definições estáveis de identidade, afinidade e estado civil. Para isso, já não contam com o recurso intelectual do matrimônio, e não confiam na vontade individual, que parece demasiado frágil. Voltam-se para o vínculo biológico, no exato momento em que o progresso científico permite a liberação das restrições biológicas.

2. Na França, há direitos paternos (a paternidade está fundada no casamento ou no reconhecimento legal como expressão da vontade), porém não direitos maternos (a maternidade é considerada uma questão de biologia e de amor natural, não uma questão do direito). A relação mãe-filho é vista

\footnotetext{
* [N.T.]: No original, relatedness, "condição de estar relacionado, ligado", dificilmente traduzível por palavra perfeitamente correspondente.
} 
como um vínculo natural, que torna a norma social da maternagem muito mais forte do que a da paternagem, no momento mesmo em que as mulheres, nos aspectos profissionais e públicos de suas vidas, são pressionadas a se comportarem como os homens. Por que as feministas francesas não foram capazes, até agora, de enfatizar essa ausência de direitos maternos? Como resposta, eu gostaria de sugerir que, após um primeiro período em que as feministas francesas estiveram divididas quanto ao tema da maternidade - algumas defendendo os direitos das mães, outras defendendo o direito de não ser mãe - elas esqueceram a primeira posição, cederam ao governo de Vichy e a abandonaram à direita reacionária.

3. As políticas sociais relativas às mães são políticas de salário mínimo, e as relativas aos idosos incluem auxílios e, principalmente, concessão de status de assalariado aos familiares prestadores dos cuidados. Por que essa enorme diferença? Sugiro que as políticas relativas à criação de filhos foram concebidas, após 1968, sob a influência das correntes de esquerda, de modo a desnaturalizar e a profissionalizar a atividade de cuidar de crianças em um período de pleno emprego. As políticas relativas ao acompanhamento dos idosos, ao contrário, foram concebidas nos anos 1990, sob a influência da direita, com vistas a remoralizar as famílias em um período de desemprego. Essa diferença histórica explica, porém não justifica, o claro fracasso das políticas sociais em alcançar seus objetivos de diminuição das desigualdades sociais entre diferentes tipos de famílias. Atualmente, as transformações contemporâneas tanto do parentesco prático quanto legal reforçam a desigualdade entre mães solteiras pobres e redes familiares da classe alta, redes nas quais a sucessão de casamentos e nascimentos garante para os filhos, mais que nunca, os recursos sociais.

Recebido em 23 de maio de 2006

Aprovado em 10 de julho de 2006

Tradução de Amir Geiger

Florence Weber é professora de sociologia na Ecole Normale Supérieure e pesquisadora do Centre d'Etudes de l'Emploi, Paris, França. E-mail: < Florence. Weber@ens.fr> 


\section{Notas}

${ }^{1}$ Cf. Weber (2001). Essa concepção não está distante dos "circuitos de comércio" de Zelizer (2004). Ver também Zelizer (2005:35), em que essa abordagem é designada como uma teoria das "vidas interligadas", oposta à dos "mundos hostis" e à do tipo "nada mais que".

2 “'Dar atenção' é um reconhecimento — cultural e individualmente moldado — de que há necessidade de se prestarem cuidados. 'Tomar conta' envolve assumir alguma responsabilidade por certa necessidade reconhecida e determinar o modo de responder a ela. 'Dar assistência' é o trabalho físico e direto, e geralmente requer contato entre aquele que cuida e aquele que é objeto de seus cuidados. Dar dinheiro ou sustentar é uma forma de 'tomar conta', mais que de 'cuidar', pois não pode atender/satisfazer diretamente às necessidades humanas, ainda que possa fornecer recursos para fazê-lo. O quarto estágio é o de 'receber cuidados', no qual a pessoa que é objeto de cuidado responde aos cuidados recebidos. É importante notar que embora todos os seres humanos, com efeito, necessitem de algum tipo de cuidado que deverá ser suprido por outros, as necessidades, a definição de quem presta os cuidados e as noções de bons cuidados são construídas culturalmente. Reconhecê-lo foi central para nossos propósitos" (Tronto apud Ganesh et alii 2005:05) . * [N. T.] O trecho citado propõe uma série em que todas as expressões inglesas empregam a palavra care, "(ter) cuidado", "(ter/dar) atenção" — nos vários sentidos que cuidar/dar cuidados também têm em português, mas que não são diretamente traduzíveis de modo a formar uma série equivalente: caring about, taking care of, care-giving, care-receiving.

${ }^{3}$ Cf. Dumont (1971); para essa discussão, veja-se Weber (2002).

${ }^{4}$ Essa situação não é excepcional, ainda que não seja tão freqüente quanto poderíamos pensar ao ouvirmos os relatos cheios de ansiedade sobre a "crise da família". Na França, em 1999, 13\% das crianças com menos de 15 anos viviam em um lar com apenas um dos pais (na maior parte dos casos, a mãe).

${ }^{5}$ Freqüentemente, mas não sempre, os pais (homens) divorciados desaparecem dos lares de cuidado; mas quando eles morrem, seus filhos ainda assim são seus herdeiros, exceto quando há algum processo judicial de contestação da paternidade. Tal processo é possível — porém longo e trabalhoso — desde 1972. Há poucas centenas de casos anuais.

${ }^{6}$ Esses estudos de caso foram publicados em Weber 2005.

${ }^{7}$ Para uma interessante discussão sobre essa afirmação do ponto de vista da lei francesa, ver Iacub (2005); para um levantamento sociológico entre mães que abortaram, ver Boltanski (2005).

${ }^{8}$ Tomo o termo de empréstimo a Carsten (2000). 
Figura 1. O primeiro lar de cuidado de Berenice

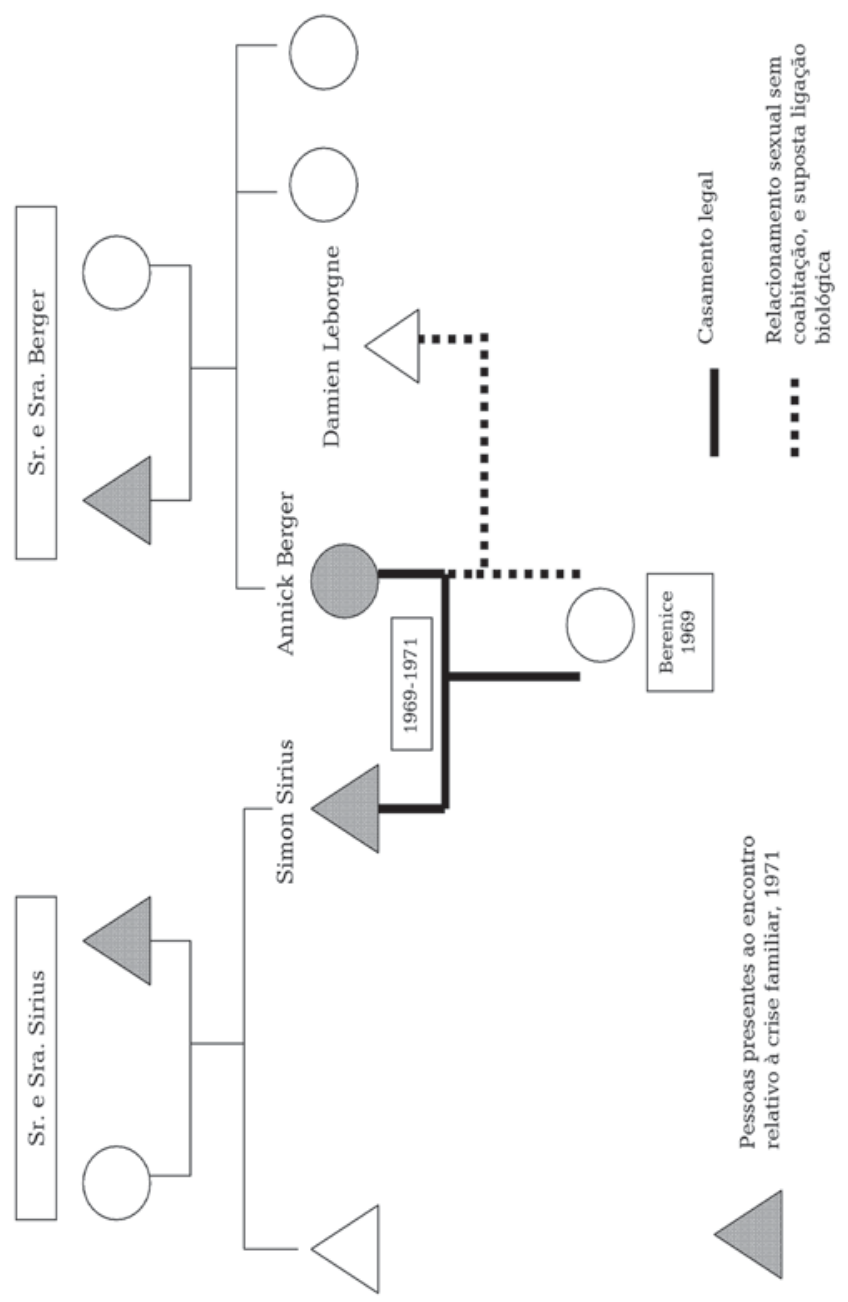


Figura 2. O segundo lar de cuidado de Berenice con Nathan, o padrasto

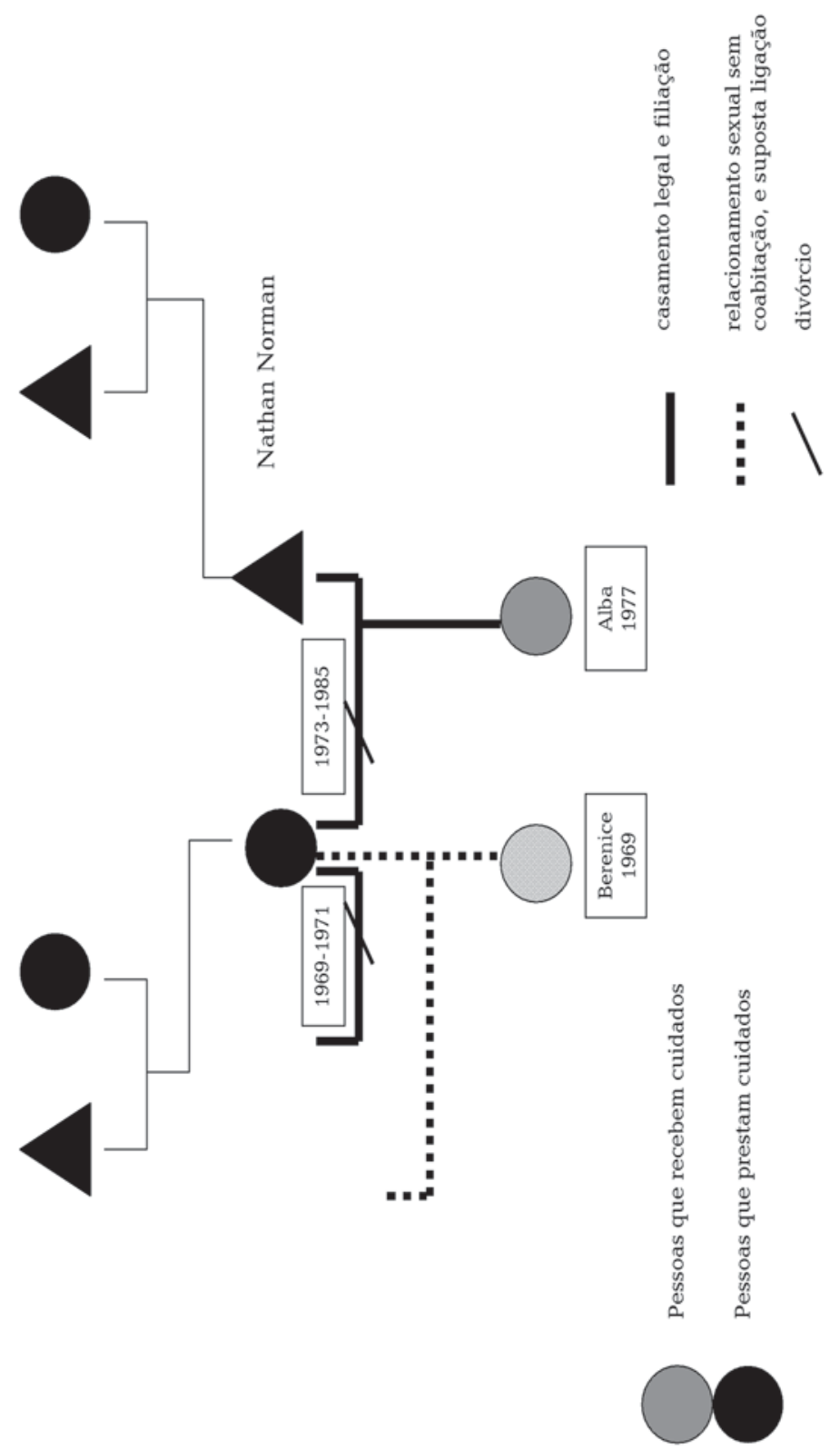


Figura 3. Quatro linhas de sucessão, incluindo a de Berenice

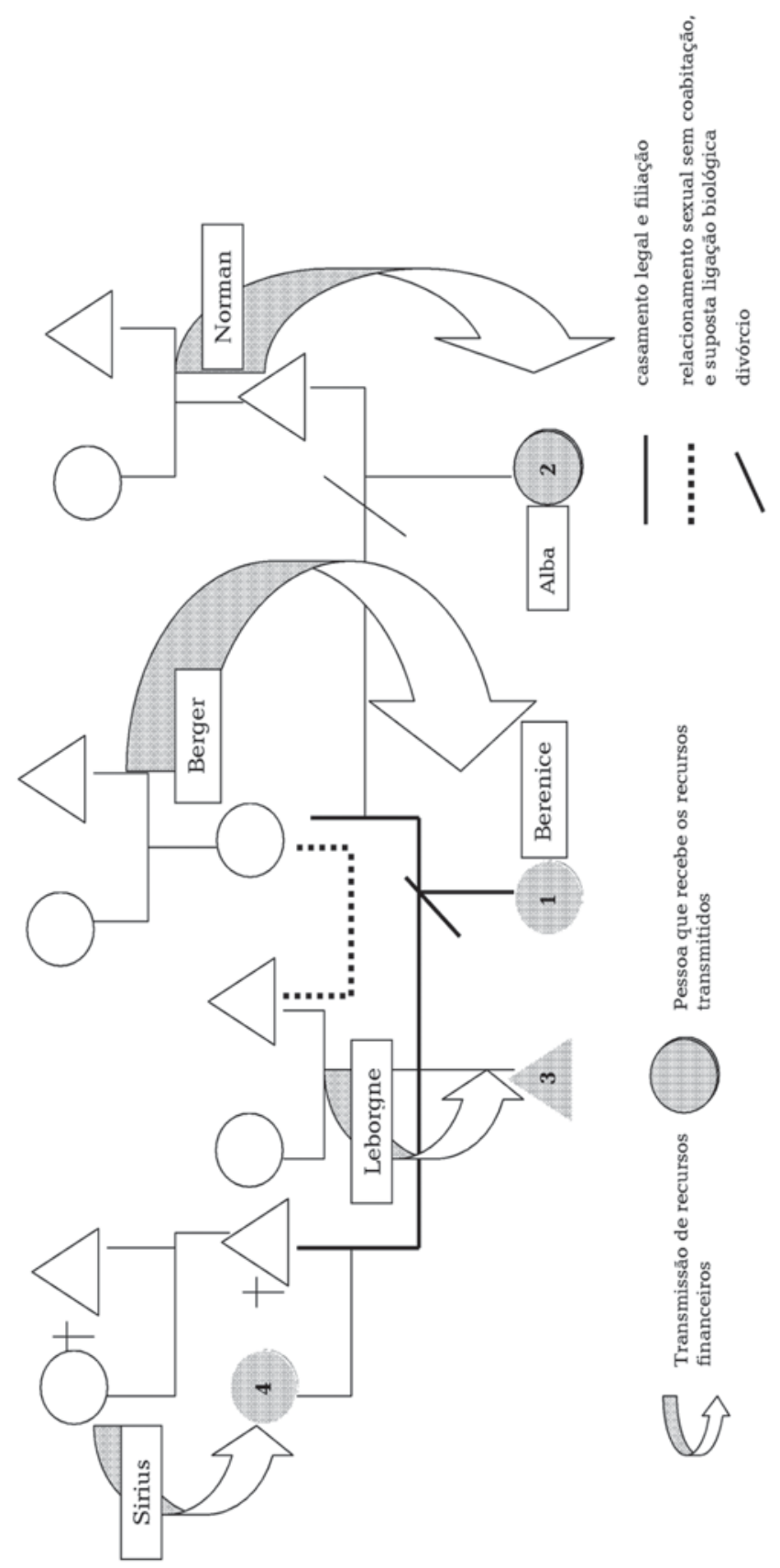


Figura 4. Helena, mãe solteira desprovida pelo governo e por instituições de caridade

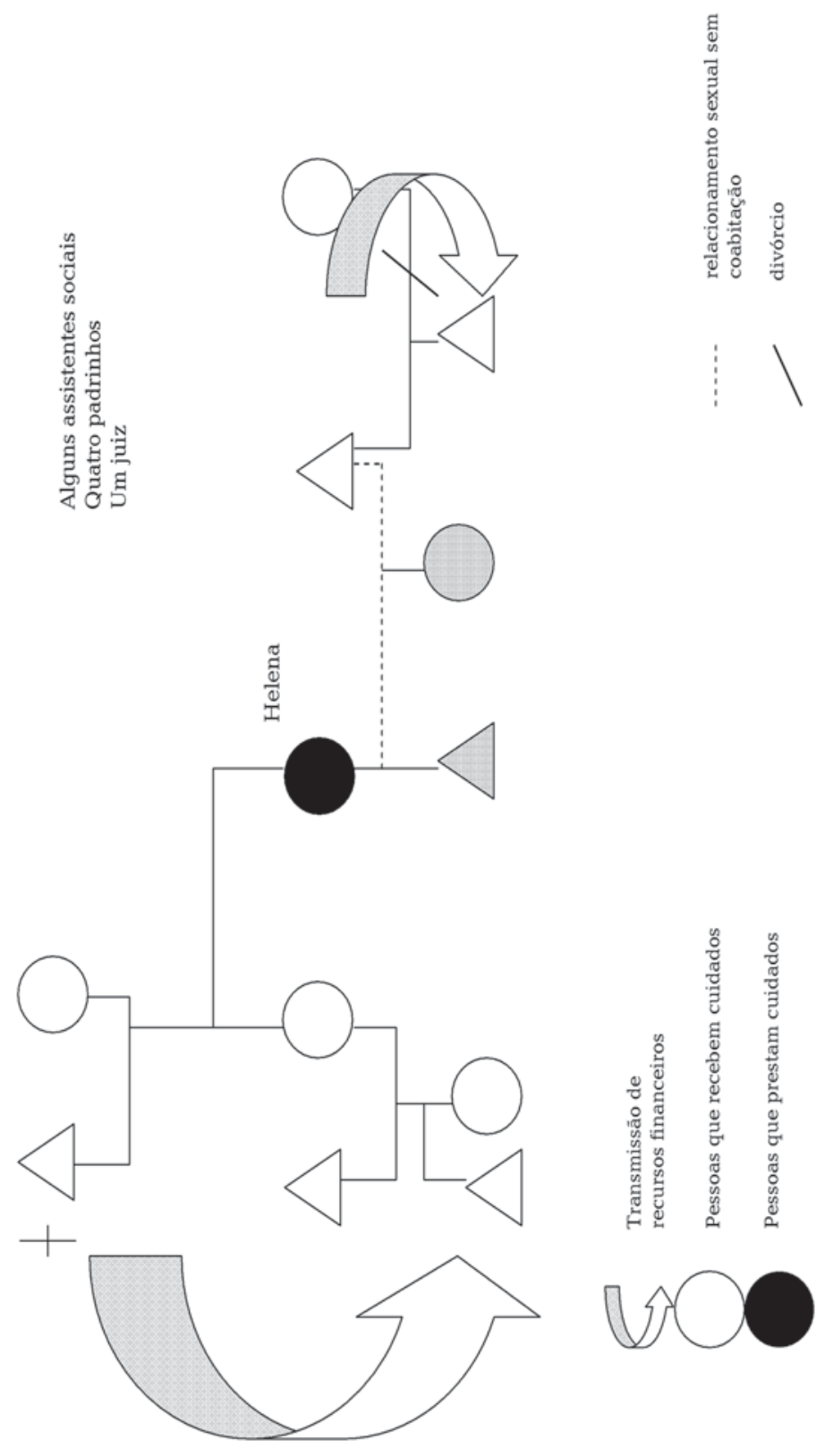


Figura 5. O caso de Saliha, sozinha com a mãe que sofre de Alzheimer

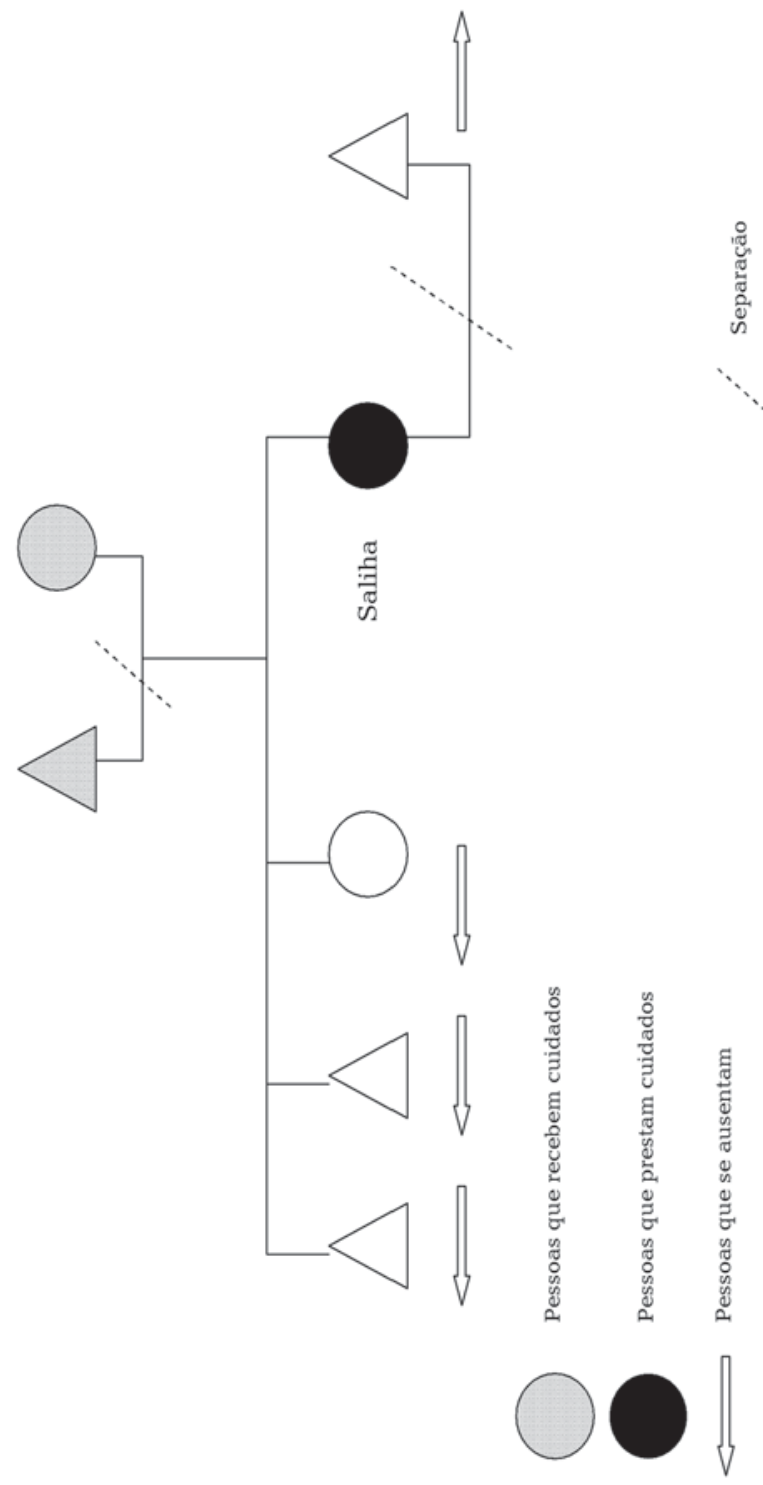




\section{Referências bibliográficas}

BOLTANSKI, Luc. 2005. La condition foetale. Paris: Le Seuil.

BOURDIEU, Pierre. 1977. Outline of a theory of practice. Cambridge: Cambridge University Press.

CARSTEN, Janet (org.). 2000. Cultures of relatedness: new approaches to the study of kinship. Cambridge: Cambridge University Press.

DUMONT, Louis. 1971. Introduction à deux théories d'anthropologie sociale. Paris: Gallimard.

GANESH, Kamala; PALRIWALA, Rajni; RISSEEUW, Carla. 2005. Care, culture and citizenship. Revisiting the politics of the Dutch welfare state. Amsterdam: Het Spinhuis.

IACUB, Marcela. 2005. L'Empire du ventre. Paris: Fayard.

THÉBAUD, Françoise (org.). 1993. Histoire des femmes en Occident. Le $20^{\text {ème }}$ siècle. v.5. Paris: Seuil.

TRONTO, Joan C. 1993. Moral boundaries. A political argument for an ethic of care. London/ New York: Routledge.

WEBER, Florence. 1989. Le travail à-côté. Etude d'ethnographie ouvrière. Paris: INRA-EHESS.
. 1998. L'honneur des jardiniers. Les potagers dans la France du $20^{\text {ème }}$ siècle. Paris: Belin.

. 2001. "Settings, interactions and things. A plea for multi-integrative ethnography". Ethnography, 2(4):475499.

. 2002. "Pour penser la parenté contemporaine". In: D. Debordeaux e P. Strobel (orgs.), Les solidarités familiales en questions. Entraide et transmission. Paris: LGDJ. Coleção Droit et Société, v.34. pp.73-106.

2005. Le sang, le nom, le quotidien. Sociologie de la parenté pratique. Paris, La Courneuve : Aux Lieux d'Être.

. 2006. L'économie domestique. Ethnographie du quotidien 1. Paris, La Courneuve: Aux Lieux d'Être.

ZELIZER, Viviana. 2004. "Circuits of commerce". In: J. C. Alexander, G. T. Marx, e C. Williams (orgs.), Self, social structure, and beliefs: explorations in sociology. Berkeley: University of California Press. pp. 122-44.

. 2005. The purchase of intimacy. Princeton: Princeton University Press. 


\section{Resumo}

Com base em três casos etnográficos, a autora explora as discrepâncias, no contexto francês, entre paternidade e maternidade em seus aspectos legais e ideológicos, entre maternagem e paternagem em suas dimensões morais e afetivas, e entre diferentes aspectos dos cuidados relativos a crianças e pais idosos dependentes, abordando a questão de um ponto de vista triplo: da responsabilidade legal (quem deve pagar), das transações econômicas (quem dá e quem recebe assistência paga e não-paga) e dos sentimentos morais (sentido de vínculo natural, senso de dever, amor eletivo e sentimentos construídos no dia-a-dia). São empregados os conceitos de lares de cuidado e de linhas de sucessão para mostrar de que modo as dimensões econômicas e afetivas do parentesco estão interligadas. Por fim, a autora procura compreender por que as políticas sociais francesas criaram recentemente uma categoria de assalariado para filhas que cuidam dos pais idosos, sem que haja nenhuma categoria correspondente para mães que cuidam dos filhos.

Palavras-chave: Parentesco, Economia dos cuidados, Sentimentos, Políticas sociais

\section{Abstract}

By looking at three ethnographic cases, the author explores discrepancies between French notions of paternity and maternity in their legal and ideological aspects, between fathering and mothering in their moral and affective dimensions and between different aspects of caring in the cases of dependent children and of aging parents. The author analyzes these discrepancies from the triple point of view of legal responsibility (who should pay), economic transactions (who gives and receives unpaid and paid care) and of moral feeling (feelings of natural linkage, sense of duty, elective love and quotidian, constructed feeling) She uses the concepts of households of care and lines of transmission to show how the economic and affective dimensions of kinship are connected, trying to understand why French social policies have recently invented a salaried status for caring daughters, but none for caring mothers.

Key words: Kinship, Economics of care, Feelings, Social policies. 